\title{
História através dos pássaros
}

\section{History Through Birds}

\author{
Felipe Ferreira VANDER VELDEN ${ }^{1}$ \\ http://orcid.org/0000-0002-5684-1250 \\ ${ }^{1}$ Universidade Federal de São Carlos \\ Departamento de Ciências Sociais \\ Via Washington Luís, Km 235, São Carlos, SP, 13.565-905, Brasil \\ felipevelden@yahoo.com.br
}

Obra resenhada:

JACOBS, Nancy J. Birders of Africa: History of a Network. New Haven \& London: Yale University Press, 2016. 325p.

Desde que Robert Delort, aliando a leitura de fontes históricas variadas com os conhecimentos da zoologia, declarou, em 1984, que "os animais têm uma história”, a assim chamada História Ambiental vem paulatinamente deixando sua preocupação clássica com a constituição de paisagens (Cronon, 1983; Schama, 1996) e passando mais e mais a se interessar pelos animais como produtores de história. "History is not just for people anymore”, declara Nancy Jacobs (Jacobs, 2016, p.8) nesta sua incursão pelas trajetórias das relações entre povos e pássaros no continente africano. Retomando a célebre assertiva do antropólogo Claude Lévi-Strauss, Jacobs sustenta que os pássaros são bons para pensar; neste caso, para pensar a história da África e das relações entre populações africanas e estrangeiros, negros e brancos, nas complexas articulações entre ciência, conhecimento local, política e poder, colonialismo e descolonização, raça, nação, trabalho, honra, hierarquia e desigualdade,

Recebido: 07 mai. 2018 | Aceito: 21 mai. 2018

http://dx.doi.org/10.1590/0104-87752018000300011

Varia Historia, Belo Horizonte, vol. 34, n. 66, p. 851-854, set/dez 2018 
colaboração e violência. A história da África pode ser escrita, assim, da perspectiva de sua rica avifauna ou, mais precisamente, das milenares interações entre humanos e aves naquele continente, captadas por meio na análise do conhecimento historicamente produzido pelas pessoas sobre os pássaros em solo africano.

É fato que, apesar da centralidade da África na história da América portuguesa e do Brasil, conhecemos pouco do que se passa e do que se passou do outro lado do Atlântico. E, se começamos a saber mais das histórias e das culturas na África subsaariana em distintas disciplinas acadêmicas no país, a natureza africana - e, sobretudo, as relações entre grupos humanos e seres naturais - ainda chega até nós basicamente por meio de imagens estereotipadas e espetacularizadas dos safaris, cujo efeito principal está justamente no apagamento da diversidade e da historicidade das relações entre humanos e não humanos ali (Igoe, 2017). A África, megadiversa em culturas, é também exuberante em pássaros (menos conhecidos do público do que seus icônicos mamíferos), que Jacobs busca historicizar por meio da atenção às atividades dos agentes que ela chama de birders, que traduzimos como "passarinheiros" - todos aqueles que, na história do continente, se interessaram em se aproximar das e seguir as aves, por razões variadas, vernaculares, ornitológicas e recreacionais (Jacobs, 2016, p.9). Descortinar a rede (network) que conecta estes birders aos pássaros e demais agentes não humanos na história antiga e recente da África constitui o objetivo primordial do livro.

Em oito capítulos, divididos em duas partes (a primeira, de caráter mais estrutural, focalizando o período anterior à colonização até o século XIX; a segunda, com foco em trajetórias individuais, centrada na consolidação hegemônica da ornitologia científica no século XX e na emergência do birdwatching como fenômeno global), a autora nos traz uma detalhada análise da África e suas muitas assimetrias - entre negros e brancos, colônia e império, ciência e conhecimento nativo. Mais do que apostar, contudo, numa pétrea oposição entre esses termos, Jacobs argumenta que a história da produção de conhecimento sobre a África é muito mais uma história de colaboração e interpenetração do que uma de (simples) exclusão. Sem negar a violência colonial (inclusive 
na ciência, fortemente racializada), o livro sugere que o estudo dos saberes sobre as aves africanas pensados como modalidades de cooperação entre conhecimentos, práticas e técnicas africanas e estrangeiras (europeias e norte-americanas) é a forma mais acurada para conhecermos um pouco da trajetória de gente comum que, na África ao sul do Saara (e, com especial foco, nas suas partes meridional e oriental anglófonas), esteve envolvida, de muitas maneiras, com as ricas faunas ornitológicas locais e seu estudo. A metodologia empregada é heteróclita - variando entre arquivos históricos, diários de viajantes, coleções museológicas, textos de estudantes, obras de arte, memórias e entrevistas com "passarinheiros" (profissionais e amadores) africanos - porque apenas assim, defende Jacobs, pode-se escrever a história desses sujeitos menores para os quais as elites olharam, mas sobre os quais pouco escreveram com profundidade (Jacobs, 2016, p.22-23).

Não se trata, o livro, de uma história (natural) ornitológica africana, nem tampouco de uma história da ornitologia em África, do conhecimento a respeito dos pássaros. Poder-se-ia definir a obra de Jacobs como uma reflexão sobre a história da relação entre humanos e aves naquele continente, uma história da história da ornitologia desenvolvida por lá. História que, coordenada desde o século XVI pelo império, narra a trajetória de consolidação da ciência, com o paulatino apagamento dos saberes vernaculares sobre as aves e a crescente hierarquização (sobretudo racializada) dos saberes. Traços desses conhecedores e conhecimentos originais africanos (e dos eventos que os colocaram diante de saberes e poderes europeus), evidentemente, permanecem nas espécies e nos espécimes - muitos nos seus nomes e nos "inert envelop[s] emptied of the living bird” (Jacobs, 2016, p.97). Recuperá-los, nos interstícios entre a zoologia moderna e os vernáculos nativos, constitui uma das tarefas da autora - o que ela faz, nos capítulos 5 a 8, reconstruindo as trajetórias individuais de "passarinheiros" africanos, alguns dos quais tiveram papel crucial no desenvolvimento da ornitologia naquele continente.

Este livro de Nancy Jacobs, assim, constitui-se, por sua novidade e tratamento refinado da temática, em excelente umbral de acesso a todos os interessados na história ambiental em geral, e na história das relações 
(majoritariamente assimétricas) entre humanos (negros e brancos, cientistas e assistentes) e não humanos (aves) em particular, na África subsaariana e na ciência. Sua análise, fundada na ideia de acessar a história - do nível estrutural às histórias de vida pessoais - a partir das aves (e das relações entre distintos grupos humanos e a avifauna), permite compreender muito das redes que conectaram a África ao resto do mundo, e produzir algo como uma história africana do ponto de vista das associações nacionais, regionais ou locais com os pássaros. Deve agradar — por sua discussão pormenorizada do que seriam, a primeira vista, questões historiográficas menores - também àqueles que desejam aprofundarse na micro-história africana, sejam especialistas (nas ciências sociais e nas ciências biológicas), seja o leitor comum - "passarinheiro" ou não - disposto a conhecer mais sobre as savanas e florestas que, densas em pássaros (2355 espécies), nos observam na margem oposta do oceano (Jacobs, 2016, p.239).

\section{REFERÊNCIAS BIBLIOGRÁFICAS}

CRONON, William. Changes in the Land: Indians, Colonists, and the Ecology of New England. New York: Hill \& Wang, 1983.

DELORT, Robert. Les animaux ont une histoire. Paris: Seuil, 1984.

IGOE, Jim. The Nature of Spectacle: on Images, Money, and Conserving Capitalism. Tucson: The University of Arizona Press, 2017.

JACOBS, Nancy J. Birders of Africa: History of a Network. New Haven \& London: Yale University Press, 2016.

SCHAMA, Simon. Paisagem e memória. São Paulo: Companhia das Letras, 1996. 